\title{
Retraction: Inhibition of constitutively active Jak-Stat pathway suppresses cell growth of human T-cell leukemia virus type 1-infected T-cell lines and primary adult T-cell leukemia cells
}

\author{
Mariko Tomita ${ }^{1}$, Hirochika Kawakami ${ }^{1}$, Jun-nosuke Uchihara ${ }^{1,2}$, Taeko Okudaira ${ }^{1,2}$, Masato Masuda ${ }^{2}$,
} Takehiro Matsuda ${ }^{1,3}$, Yuetsu Tanaka ${ }^{4}$, Kazuiku Ohshiro ${ }^{5}$, Naoki Mori ${ }^{1 *}$

\section{Retraction}

The authors of this article [1] would like to retract it. It contains duplicated Tax and actin Western blotting images. These misrepresentations do not change the scientific conclusion of the paper. The first author, Mariko Tomita and last author, Naoki Mori, take full responsibility for the duplication and misrepresentation of the figures in this paper, state that none of the coauthors were involved in or aware of these events, and apologizes to the readers, reviewers and editors of Retrovirology for publishing these duplicated images.

\footnotetext{
Author details

'Division of Molecular Virology and Oncology, Graduate School of Medicine, University of the Ryukyus, 207 Uehara, Nishihara, Okinawa 903-0215, Japan. ${ }^{2}$ Division of Endocrinology and Metabolism, Faculty of Medicine, University of the Ryukyus, 207 Uehara, Nishihara, Okinawa 903-0215, Japan. ${ }^{3}$ Division of Child Health and Welfare, Faculty of Medicine, University of the Ryukyus, 207 Uehara, Nishihara, Okinawa 903-0215, Japan. ${ }^{4}$ Division of Immunology,

Faculty of Medicine, University of the Ryukyus, 207 Uehara, Nishihara,

Okinawa 903-0215, Japan. ${ }^{5}$ Department of Internal Medicine, Naha

Prefectural Hospital, 1-3-1 Yogi, Naha, Okinawa 902-8531, Japan.

Received: 16 December 2010 Accepted: 6 January 2011

Published: 6 January 2011

\section{Reference}

1. Tomita M, Kawakami H, Uchihara JN, Okudaira T, Masuda M, Matsuda T, Tanaka Y, Ohshiro K, Mori N: Inhibition of constitutively active Jak-Stat pathway suppresses cell growth of human T-cell leukemia virus type 1infected T-cell lines and primary adult T-cell leukemia cells. Retrovirology 2006, 3:22.
}

doi:10.1186/1742-4690-8-1

Cite this article as: Tomita et al:: Retraction: Inhibition of constitutively active Jak-Stat pathway suppresses cell growth of human T-cell leukemia virus type 1-infected T-cell lines and primary adult T-cell leukemia cells. Retrovirology 2011 8:1.

\footnotetext{
* Correspondence: n-mori@med.u-ryukyu.ac.jp

'Division of Molecular Virology and Oncology, Graduate School of Medicine, University of the Ryukyus, 207 Uehara, Nishihara, Okinawa 903-0215, Japan Full list of author information is available at the end of the article
}

Submit your next manuscript to BioMed Central and take full advantage of:

- Convenient online submission

- Thorough peer review

- No space constraints or color figure charges

- Immediate publication on acceptance

- Inclusion in PubMed, CAS, Scopus and Google Scholar

- Research which is freely available for redistribution 